\title{
George Grant's cosmopolitan critique of education
}

\author{
La critique cosmopolite de l'éducation, de \\ George Grant
}

\section{La crítica cosmopolita a la educación de George Grant}

\author{
William F. Pinar \\ University of British Columbia, Canada
}

\begin{abstract}
A cosmopolitan curriculum encourages students to grapple with the "problem of my life and flesh." That "problem" is simultaneously autobiographical, historical, and biospheric. It is a problem to be studied as it is lived through and acted upon. What makes curriculum "cosmopolitan" is its subjective structuration, informed by and addressed to the historical moment, within which subjectivity occurs and takes social form. Cosmopolitan curriculum may claim disciplinary and/or interdisciplinary associations; its educational significance is its provision of passages between the past and present.
\end{abstract}

Key Words: cosmopolitanism; curriculum; subjectivity; George Grant; history.

\section{RESUMEN}

Un currículo cosmopolita anima a los estudiantes a luchar con el "problema de la vida y la carne". Este "problema" es al mismo tiempo autobiográfico, histórico, biosférico. Es un problema para ser estudiado mientras es vivido y obrado. Lo que hace a un currículo "cosmopolita" es la estructuración subjetiva, puesta al corriente por y dirigida hacia el momento histórico, dentro del cual ocurre y toma forma la subjetividad. El currículo cosmopolita puede reclamar asociaciones disciplinarias y/o interdisciplinarias; su significación educativa es su provisión de pasajes entre el pasado y el presente.

Descriptores: cosmopolitismo; currículo; subjetividad; George Grant; historia. 


\title{
RÉSUMÉ
}

Un programme d'études cosmopolite encourage les étudiants à confronter le "problème de ma vie et de ma chair.» Ce "problème» est à la fois autobiographique, historique, biosphérique. Il est un problème à étudier tout en le vivant et en en suivant les indications. Ce qui fait qu'un programme est «cosmopolite» est sa structuration subjective éclairée par le moment historique et s'adressant à lui, au sein duquel la subjectivité a lieu et prend une forme sociale. Un programme cosmopolite peut se réclamer d'associations disciplinaires et/ou interdisciplinaires; son importance éducative se trouve dans le fait qu'il offre des dispositions pour effectuer des passages entre le passé et l'avenir.

Mots clés: cosmopolitisme; curriculum; subjectivité; George Grant; histoire.

\section{Introduction}

"Who is to recount how and when and where private anguish and public catastrophe may lead men to renew their vision of excellence?"

George Grant (1969, p. 132)

\begin{abstract}
Apoir SERIES Of JUXTAPOSITIONS DEMONSTRATING DISSONANCE AND RESONANCE, a cosmopolitan curriculum invites that ongoing self-engagement sometimes associated with solitude. But even alone, one is embedded in a world that is not only human and historical. ${ }^{1}$ In our time, it seems subjectivity is snared by the emergency of everyday life, wherein experience " $[c]$ an neither be possessed nor internalized... too 'large' to be contained within the boundaries of the individual self or ego" (Foster, 2005, p. 176). That sense of emergency eviscerates experience as worldly.

Worldliness implies immanence rather than transcendence - at least, transcendence conceived as split-off from the world. The magnetic medium of immanence is subjectivity, as "the self becomes an emblem of the real" (Gordon, 1996, p. 242). Passionate lives subjectively expressed through public service invite self-understanding through self-overcoming, as "it is only through history that man comes to know himself" (Jay, 2005, p. 231). One can also come to know history through oneself, requiring reactivations of history now effaced by North America's cultures' collapse into functionality. ${ }^{2}$
\end{abstract}

Focused less on institutional allocations of coursework ${ }^{3}$ than on its subjective structuration, a curriculum for cosmopolitanism cultivates comprehensions of alterity, including the self-knowledge that enables understanding of others. ${ }^{4}$ Such understanding can never be an "objective" for which teachers can be held "accountable." Understanding is instead a retrospective judgment rendered by those who have been reconfigured by what they have studied and how they have lived (Radhakrishnan, 2008, p. 226). While the particulars vary, the subject's non-coincidence (Pinar, 2011, pp. 158-159) with them provides ongoing opportunity to learn from experience, to undergo educational experience. A cosmopolitan curriculum can require relocation.

Working in Canada has provided me an ongoing opportunity to understand my subjective formation as an "American." While that identity does not summarize 
me, it is no minor key of the chord I strike when "I sing myself" either. Upon arrival in Vancouver in 2005, I felt "gas-lighted," an experience of familiarity that was deceptive. ${ }^{6}$ While hardly my first time in Canada, it was the first of extended duration. I suspected that moving to British Columbia could constitute a cosmopolitan experience. To begin to understand where I was, I supplemented study ${ }^{7}$ of everyday life with the study of several Canadian thinkers: Northup Frye, Harold Innis, George Grant, Marshall McLuhan, Margaret Atwood, John Ralston Saul. Making no claims for their comprehensiveness, I have found that studying their works provided entries into the country that seemed familiar but falsely so.

The writings of George Grant ${ }^{8}$ register a Canada that is past. The nation he lamented $^{9}$ has changed dramatically during the last fifty years. To this outsider, the portrait remains recognizable. Grant's critique of technology, temporality, and education has forced me to question that aspect of my subjective formation indelibly associated with the country of my birth and upbringing, focused on the pragmatism ${ }^{10}$ that I had embraced as a graduate student in the late 1960s. ${ }^{11}$ Studying George Grant places ${ }^{12}$ me not only nationally but also temporally embedded in the History to which, for Grant, time had become reduced. Such emplacement - temporal as well as spatial, as I confront the historical moment as well as nation wherein I came to form - reactivates the past in the present. That reactivation, I suggest, constitutes an occasion of a cosmopolitan curriculum.

\section{The Past in the Present}

"[T] he [contemporary] purpose of education is to gain knowledge which issues in the mastery of human and non-human nature."

George Grant (1969, p. 118)

If allegory juxtaposes eternity ${ }^{13}$ and contingency, ${ }^{14}$ the present historical moment for George Grant, it was the post-war period extending through the 1960s - was at once the end of one day and the start of another. Like his colleague Harold Innis, ${ }^{15}$ Grant (1959/1966) invoked a mythological image - that of the owl of Minerva taking flight at twilight ${ }^{16}$ - to denote its movement (p. 5). Citing Hegel, Grant acknowledged that this fading of the light invites reflection on the day ending and on the night now commencing, a moment for philosophy in the expansive sense ${ }^{17}$ Grant intends. "[H] uman beings only pursue philosophy,"18 Grant (1959/1966) writes, "when an old system of meaning is coming to the end of its day" (p. 5). What he means by "old system of meaning" is ancient, indeed.

What were the markers of "twilight" in his day? One was the 1957 Sputnik satellite, inaugurating fifty years of "school reform" in the United States ${ }^{19}$ and in Canada precipitating political events that would, for Grant, indicate the end of the independence of nation. "During the excitement over Sputnik," Grant (1959/1966) wrote: 
it was suggested that the Americans were deeply depressed by the Russian success. I thought this was a wrong interpretation. Rather there was a great sign of relief from the American elites, for now there was an immediate practical objective of competition to be achieved, a new frontier to be conquered - outer space. It provided further excuse not to think about what will make life meaningful when practical problems are settled... (pp. 87-88)

If practical problems are never finally settled, can questions of meaning be deferred indefinitely?

Sputnik became the precipitating event for a constitutionally questionable federal intervention in the education of the American public. ${ }^{20}$ Grant is focused on Canada; Sputnik provided the rationale for the United States to stipulate the status of its ally in this perilous phase of the Cold War. Canada remained the neighbor to the north, but in the national panic over Sputnik - suggesting, as it did, that US military superiority over the Soviet Union had ended - "neighborliness" meant merely proximity, not congeniality. Grant (1959/1966) minced no words:

It is only necessary to see how rocked our society was when the Russians got that piece of metal up into the sky before we did. They had beaten us at our own game and the game we consider important. So from our business and military leaders the cry goes up that we must intensify our history-making activities, we must be tougher in our education so that we can produce together history-makers. (pp. 24-25)

Grant knew the blame game Sputnik started. Responsibility for the fiasco was shuttled swiftly away from government, the space program, or the US military, and onto an institution by its nature ill-suited to produce a national mobilization. ${ }^{21}$ By relocating responsibility for Sputnik from government to schools, officials sidestepped accountability and ensured that schools would not escape theirs.

Sputnik signaled that the post-war period in public education had ended. ${ }^{22}$ There would be a decade - the 1960s - when progressivism remerged and even more radically so, intensified by its intertwining with the racial, gender, and anti-Vietnam War politics of the period. But with Nixon's election in 1968, the long night began. The military competition of the Cold War had accelerated the technologization of culture and of the economy, prompting politicians and the increasingly powerful defense industry ${ }^{23}$ to pressure schools to produce more scientists and engineers. By mid-century, bureaucratization - judged "progressive" in the early twentieth century, as it promised equal treatment - seemed only oppressive. Grant (1959/1966) goes so far as to say: "Every instrument of mass culture is a pressure alienating the individual from himself as a free being" (p. 7). While today this seems too simple, too bifurcating, it is not mistaken. Now schools could curb creativity as they were forced to institutionalize instrumentalism: with "reform," schools could produce scientists who could produce technology that ensured, presumably, military and economic national superiority. 
Such a scheme restated an American confidence in engineering ${ }^{24}$ at least a century old, a nationally specific modernity summarized as "Americanism," at least in Germany during the 1920s. ${ }^{25}$ It had been Germans - Adorno and Horkheimer who had demonstrated that modernity meant the instrumentalization of reason, its devolution into calculation and manipulation. In education, "reason" became institutionalized as "objectives" whose organization of "learning experiences" promised to produce "outcomes" assessed by standardized examinations. While Grant was charting the calamity befalling Canada, Jerome Bruner was assuring Americans that any child could be taught sophisticated science at any age (Pinar, 2012, p. 105, 108, 183, $215,216)$. It was more mathematicians, scientists, engineers, and technologists that the "power elite" wanted then, and wants still (Pinar, 2012, pp. 19-20). Within the curriculum, one subset of instrumental rationality was academic vocationalism - training students to think as professional scientists or mathematicians or historians think - and it remains today, evident in the revision of the teaching of history in Canada. ${ }^{26}$ Too rarely is reason imagined as enabling us to travel to destinations unknown at the outset, as our conveyance through uncharted realms. Grant (1959/1966) remembers reason's ancient offering: "The old idea that 'the truth shall make you free,' that is, the view of reason as the way in which we discover the meaning of our lives and make that meaning our own, has almost entirely disappeared" (p. 9).

Its disappearance was for a moment remembered, in the midst of Americanism, battling in Vietnam, embattled at home, protested and ritualized - sometime strangely - in 1960s youth cultures. "And these young people," Grant (1959/1966) speculated, "whether they know it or not, hold in their very being the remnants of that tradition, the knowledge of themselves in their freedom, even if much else from that tradition has never been theirs. Thus knowing themselves as free, they know their freedom as standing against the pressures of the society which bind them in an impersonal grip" (p. 12). Those pressures were multiple: institutional, political, racial, gendered, generational.

To loosen that grip required study ${ }^{27}$ - then, as now, not foremost on the minds of those driven to engage in a process that Marcuse imagined as "repressive desublimation." 28 Declining to coincide with "Americanism" took many forms - I have argued that "school reform" in the US represents, in part, a reverberating repudiation of those forms, an effort to "grip" youth again - and many studied those disciplines that articulated the alienation non-coincidence created. Harnessed to the militaryindustrial complex, ${ }^{29}$ schools complied with the directives of the power elite, "but this very failure of our educational institutions," Grant (1959/1966) argued:

is part of that alienation which will drive the best of our students to philosophy and theology. And these young people are the evidence that in our society profound philosophical thought is arising. They herald what may yet be, surprisingly, the dawn of the age of reason in North America. (p. 13)

Ah, the remembrance of things past. Grant was hardly alone ${ }^{30}$ in allowing himself this hope, and its mutilation by four decades of right-wing reaction does not 
diminish my determination to think our way through the calamity that shows no signs of conclusion.

Study remains out-of-sync with the instrumentalism of the present moment in the US. "Dawn" is a distant memory, and what "reason" offers us now is remembrance, the instantiation of temporality, not functionality, as the structure of subjective and social life. Associated with psychoanalysis - over which Grant was ambivalent, although preferring it to the behaviorism ${ }^{31}$ then in vogue - informed reason deciphers the past in the present, not the plotting of the future, a fantasy subject to instrumental reason. At first blush, then, it can seem odd when Grant (1959/1966) writes: "In place of it we have substituted the idea of reason as a subjective tool, helping us in production, in the guidance of the masses, and in the maintenance of our power against rival empires" (p. 9). What is "subjective" about "production," the "guidance of masses," or military "power" ${ }^{32}$ What Grant means by "subjective" is "will" - for example, the will-to-power, the historical relocation of "will" from God to man, and in modernity associated with the right to materialize whatever is possible. For me, this is decidedly "de-subjectivized" reason, but for Grant the term is obviously associated not only with whim or (subjective) bias but with human hubris, specifically the institutionalization of will in science and technology. "People educate themselves to get dominance over nature and over other men," Grant (1959/1966) regrets, and "scientific reason is what we mean by reason" (p. 9). Within "the human field," he adds, reason comes ever more to be thought of as social science, particularly psychology in its practical sense" (pp. 9-10).

To avoid this psychologistic obsession - the advent of the culture of narcissism, ${ }^{33}$ although Grant does not use the phrase - and its cult of calculation, subjective reconstruction becomes a moral striving for subjective coherence. ${ }^{34}$ That moral striving invites an allegorical restructuring of subjective experience. ${ }^{35}$ By remembering that one's experience exhibits this mythological significance - that it is not exclusively its contingency and idiosyncrasy, but also a timeless (ongoing, perhaps eternal?) ethical issue - one declines to coincide with what is, sculpting a continuous creative tensionality that curbs collapse into the quotidian while deferring disappearance into abstraction (including calculation) and moralism (and specifically, its static adherence to abstractions). Subjectivity strewn as decentered openness to reality is worldliness, not willfulness. One studies - not only sculpts - the future, becoming historical by reactivating the past, declining to coincide with the present, enabling the future to unfold. For me, these are the subjective movements of a cosmopolitan curriculum.

The force of History determines us, as victims and beneficiaries and all points in-between, as it demands that we reconstruct what it has done to us (including by ourselves), immersed in modernity obsessed with our calculations of what we can do. "The idea that we make history and that this is what is important," Grant (1959/1966) appreciates,

is so completely taken for granted that we hardly think of it, let alone question it. The dominance of this spirit is seen in the activities which are considered most important in North America: those of the engineers, the businessmen, 
and the administrators. These are the people who are really doing something, because they are changing the world. We see it negatively in the activities which are not considered important: those of the artists, the lovers, the thinkers, and the people of prayer, for these are all activities which do not change the world. (pp. 23-24)

While enthusiastically exported, such "Americanism" is not yet universal, not even within the Western hemisphere. ${ }^{36}$

The demand for progress as profit and the cultural homogeneity it requires translates into various agencies and institutes of intervention. Anticipating by thirty years the rhetoric of the US President Clinton's school reform - "America 2000" - as well as the symbolic significance the turn of the century would hold for billions, Grant (1969) predicted that as we move "towards" the year 2000:

we need all the institutes of urban studies and of race relations, all the centers of economic development and psychological adjustment we can get. We will have to see... how all can reach a level of educational competence to inherit the hope... Add to these the international problems of how underdeveloped countries can be brought to share in the new possibilities by accepting the conditions of modernization. (p. 29)

Here Grant anticipates the economic emergence of Brazil, China, and India, as well as increased intervention into local and national economies by the World Bank and the International Monetary Fund. Within North America, health becomes a political and even moral matter, as public expenditures on health care escalate, and therapeutic protocols of all kinds and degrees of sophistication provide opportunities for "psychological development."

The freedom - the cosmopolitanism - modernity promised dissolved in front of our eyes. Various efforts, philosophical and especially sociological, are ongoing attempts to explain how it can be that calculation and instrumentality fail to produce the realities we have decreed. The disciplinary ascendancy of sociology and its tendencies toward determinism, embedded in its self-interested assertion of the social as primary, threatens to dissolve agency altogether. It is no accident, as George Grant (1969/2001) noticed, that "sociology is central to our North American way of living" (p. 33). The passivity sociology installed was accomplished in part by its spectator theory of knowledge - that society is somehow separate from us, observable and measurable - with its authoritarian assumption that it is legitimate to study social reality scientifically. Despite the sophisticated articulation of the "crisis of western sociology" by Alvin Gouldner (1970) and his epistemologically altering acknowledgement of sociologists' "domain assumptions," the hubris of modernity, of science specifically, continued to assert itself in the disciplinary ascendency of social science - especially sociology but also psychology, itself antagonistic to psychoanalysis and, indeed, increasingly physiological. ${ }^{37}$

Grant saw that modernity's demand for nomological knowledge was not confined 
to the social sciences, imperfect if increasingly aggressive copies of natural science. Philosophy - specifically its Anglo-American versions in which logic, not experience, governed - as well as the humanities more generally became dominated by modernity's demand for "objectivity." The concept of "research" replaced "scholarship," with the latter's acknowledgement that the craft was not unrelated to the craftsman, that the scholar's undertaking was a calling not a job. In contrast to the researcher - with that concept's expectation of new discoveries and solutions to social problems - the scholar sought truth. Demands for methodological uniformity - limiting the search to what was observable and, often, measurable, not exactly a cosmopolitan move undermined the aspiration. As the calling became quiet, the name remained, as if on a tombstone. "Often people in the university like to use about themselves the more traditional word 'scholar," Grant (1986) observed, "but that word means now those who carry on "research"' (p. 37). In this conception, there is an "object" to be investigated and "outcomes" to be reported. "In the case of the humanities the object is the past," Grant pointed out (p. 37).

Reconstruction of the past may be the vocation of historians, Tony Judt ${ }^{38}$ reminds, but (as he also notes), it cannot finally be separated from the ethical demands of the present moment. The point of a cosmopolitan curriculum is not to reduce the past to the polemics of the present. For Grant, the danger seemed in the opposite direction: objectivity froze the fluidity of the past by conceiving it scientifically, as if someone here and now could, spectator-like, apprehend the dynamics of then and there. The distinctiveness of the past communicated its present significance. That significance could surface in the teaching of the past, especially to undergraduates, Grant thought, as they constituted a "public." When the past became an "object," however, its meaning for us became mute. Both the dead and the living became entombed in the present.

Instead of the past speaking to us in the present, the cult of "research" requires, Grant complained, that its protocols provide us with practical knowledge, techniques equipping us to profit from what we learn. The continuing emphasis upon "knowledge utilization" accents the practical point of what we study. Questions of meaning and significance become quaint, sometimes socially suspicious, and on occasion not intelligible at all. "Practice" has long been the byword not only of curriculum studies but teacher education, as well. It has always had a self-evident ring, even while serious theoreticians - Ted Aoki ${ }^{39}$ in Canada, James Macdonald ${ }^{40}$ and Dwayne Huebner ${ }^{41}$ in the United States - were always noticing that the concept compelled conformity, not professional inventiveness. For Grant (1959/1966), not just the public school (and the profession which prepared professionals to teach in it) had succumbed to modernity's demand for functionality; the university had, as well:

Education is concerned with teaching young people techniques by which they can do things in the world. There is almost no concern in our educational system with seeing that our young people think deeply about the purposes for which these techniques should be used... The question "for what purpose?" we leave to the ministers and even more to psychiatry, the new ministry. (p. 38)

Today, cognitive science threatens to reduce education to neurology, psychotherapy 
reduced to pharmacology. In the quoted passage above, Grant was acknowledging the psychiatric profession's increasing importance, a fact that at that time spawned an anti-psychiatry movement. ${ }^{42}$ Then, at least, psychiatry conducted its calling through conversation, asking patients to "think deeply."

Now it's all about outcomes, perhaps pharmaceutically induced. ${ }^{43}$ Just do it. Rationalizing immoral behavior as an acceptable means to whatever ends "freedom" allows, Grant (1959/1966) realized, means "personal power combined with social engineering" (p. 87). Constant craving in search of satiation, such "activism" casts its counter-disciplines - Grant lists daydreaming, sensuality, art, prayer, theoretical science, and philosophy - as "leisure," endeavors that do not "directly change the world" (p. 88). "Non-manipulative" and with "joy" and "adoration" as their "ends" - not "power" and "control" - these antiquated disciplines are now entirely optional. "Our practicality has made us uninterested in systematic thought," Grant rued, "and therefore our common moral language is seldom systematized" (p. 88). Certainly a common moral curriculum was never systematized, despite periodic calls ${ }^{44}$ for "character education," as teaching became increasingly instrumentalized, substituting social outcomes for ethical convictions. "Pragmatism ${ }^{45}$ has had such a pervasive influence in our schools," Grant thought, "because it expressed in philosophical form much that was implicit in our way of life" (p. 89).

While also Canadian - versions of US progressivism made their way north ${ }^{46}$ - the referent for Grant's use of "our" is here the United States, as the "spirit" of democracy, pioneering, and science converged in educational theory that the Puritan $s^{47}$ and later immigrants devised to produce what Grant (1959/1966) termed "egalitarian technologism" (p. 84). Desperate to find freedom in the land they took from the indigenous peoples, immigrants were willing to destroy not only what was here but also whatever remained from Europe, indeed any "social forms that limited the open society" (p. 85). "In the field of education," Grant concluded, "the decisive victory of the technical over the older studies has allowed the Open-Sesame success to consist of purely technical skills: engineering, commerce, etc." (p. 85). Were he alive today, surely Grant would add computer science to this list. ${ }^{48}$

Grant blames Dewey. ${ }^{49}$ Crediting the American philosopher's influence "in bringing about that change in our education whereby the individual has more freedom to express his individuality," Grant (1959/1966) criticizes "Dewey's belief that the intellect is an instrument for living," as that has, he believes, "directly led to a lowering of intellectual rigor in our education" (p. 94). This oversimplification Grant repeats and contradicts ${ }^{50}$ - elsewhere, displaying both ignorance of and insight into American pragmatism. In Grant's words, "to sum up, the pragmatists' conception of freedom ultimately fails because it does not understand the relation between freedom and thought, that is, between freedom and spiritual law" (p. 96). Dewey understood the complexity of relations among freedom and thought and spiritual law, ${ }^{51}$ evident in a series of expositions from How We Think (1910) through Reconstruction in Philosophy (1920) and A Common Faith (1934), but if we substitute the cult of "practicality" for "pragmatism" in Grant's statement, his critique is searing and precise.

Grant (1986) worries that "research in the humanities can less and less be seen 
as having any significance by the best professors and students" (p. 97). Why? He blames the disinclination to construe scholarship as "knowledge necessary to human existence," as addressing the enduring issues of everyday life, clearly one calling of American pragmatism. It is also Grant's calling, clear enough in his critique of objectifying the past. Instead of addressing the present moment, the humanities have become, he complains, a "museum culture" (p. 98). This is an understandable but unfortunate choice of terms, not only because many museums take their educational obligations seriously but because historiography - one of Grant's formative fields requires the reconstruction of history as it was, not only as we might find it pertinent to our situation today. ${ }^{52}$

While the relationship between the "object" of scholarship and scholarship itself is elusive and subject to ongoing reconsideration and controversy, Grant (1986) is clear that what he terms its "sacralization" - due to its "marriage with research" - is destructive (p. 98). "This stance of command necessary to research," he specifies, "therefore kills the past as teacher" (p. 99). To the extent the humanities incorporate the language and methods of the social sciences, the less social significance he feels sure they will have. ${ }^{53}$ "By thinking only about what is mathematicisable," Grant (1969) warns, "they can abstract from themselves and their own ambiguities, into the safe light of the quantifiable object. The opposite to such positivist competence is openness to all that is" (p. 45). Nowhere is that choice clearer than in contemporary educational research in the United States, now mandated to be "mathematical."

Purporting to discover "what works" in classrooms, such "research" ensures the destruction of education, its end as a public trust, now to be privatized as products sold by software companies. "Wh "Wh is important to understand," Grant knew fifty years ago, "is that the quantification-oriented behavioral sciences which have arisen from this methodological history are wonderfully appropriate for serving the tasks of control necessary to a technological society... Social sciences so defined are well adapted to serve the purposes of the ruling private and public corporations" (Grant, 1969, p. 119). As servants of capital, social scientists lose the thread of their own disciplinary conversation as they concede the primacy of priorities set by administrators and funding agencies, themselves pressured by corporatists to enlist scholars in their profiteering. Without an ongoing disciplinary conversation and one's own engagement within it, faculty cannot communicate with those in their midst, and teaching becomes the dissemination of information ${ }^{56}$ sprinkled with tips to get ahead. Selfadvancement and cynicism supplant professional ethics and disciplinary intellectual advancement. Walter Rathenau's cynical quip seems even more accurate, and Grant (1969) quotes it: "There are no specialists, only vested interests" (p. 81). Intellectual curiosity - "wonder" as Grant remarks - becomes "subsidiary to the motive of power" (p. 116). He concludes that universities within the technological societies privilege "those sciences" which promise mastery of human and non-human nature (p. 115).

What "sciences" are these? Grant references the "privileged place of mathematics in modern curricula" which, he concludes, "is related to the fact that algebra (employ if you will a more modern name) has uses in the technological society" (p. 116). Those fields without obvious utility - the arts and humanities - recede 
in curricular significance, yet another "price" now paid, Grant (1974/1998) notes, "for our long tradition of taking the goods of practical confidence and competence as self-sufficiently the highest goods" (p. 89). Like the "scavenging mongrel in the famine," Grant (1969) rues, one can claim "no merit in scenting food. Perhaps for later generations of North Americans it is now easier to turn and partake in deeper traditions than they find publicly around them" (p. 36). Finding the future requires reactivating the past.

\section{Not the End}

"Consciousness always includes within itself 'it was."”

George Grant (1969/2001, p. 53)

George Grant may seem disqualified as a cosmopolitan figure: too polemical, dated, decidedly politically incorrect. ${ }^{57}$ But a certain prickliness could be prerequisite to teaching students accustomed to facilitation instead. Fascism ${ }^{58}$ today seduces with silk gloves, but the strangle marks remain: curriculum as prepackaged online products, "interactive" but stripped of orality, the dialogical encounter Grant enacted with his students through the philosophy he communicated to them. Grant addressed the historical moment - Canada's capitulation to the US in the Cuban Missile Crisis and creeping continental economic integration, both of which he contextualized in the triumph of modernity - as he reminded students and readers that modernity obscured the eternity in which history occurred. Everyday events, even the not-soeveryday event that was Sputnik, were the moving images of eternity (Christian, $1995 / 2001$, p. xiv). Without the supernaturalism Christianity requires, such a sense of duration ${ }^{59}$ - and the allegorical character of lived experience it implies - supports the capaciousness of that subjectivity a cosmopolitan curriculum encourages. In a time of presentism, subjective reconstruction can occur through the reactivation of history, a simultaneously intellectual, subjective, and political undertaking.

In becoming historical ${ }^{60} \mathrm{I}$ become no "history-maker"- which self-aggrandizing, often exploitative activism modernity demanded - but rather attuned to temporality, to the ineffable alterity upon which everyday experience rests. It is that alterity that requires our ongoing ethical engagement. Not "research" in the sense Grant critiqued, but "study" (Pinar, 2006, pp. 109-120) in the ancient sense of spiritual exercises. Such a curriculum invites the student to grapple through sustained academic study with the "problem of my life and flesh," at once urgent and always deferred, immediate and eternal. George Grant's cosmopolitan critique of education reminds us there is still time. And he reminds us that the future is not in front of us, but in back. 


\section{Notes}

1. See Santer (2006).

2. Even indigenous cultures are threatened by capitalism and its consumption of non-functional cultural practices, despite the slowing of the now the $\$ 26$ billion tribal gambling industry (in the US). Since 1996, the Shakopee tribe - the richest tribe in the US, with each member receiving $\$ 1.08$ million a year from its casinos - has donated \$20 million to poorer tribes (Williams, 2012, August 9, p. A1, A4). Other tribes are not as charitable, as the prospect of increased income by reducing the number of tribal members has provoked disenrollment campaigns. Thousands of Indians in California have been "kicked out" of their tribes in recent years for the crime of not being of the proper bloodline (Dao, 2011, December 13, p. A1).

3. See, for instance, Nussbaum (1997), p. 70, 77.

4. See Nussbaum (1997), p. 85.

5. While the term denotes any individual living in the Americas, it connotes a citizen of the United States.

6. The phrase is derived from George Cukor's 1944 "Gaslight," starring Charles Boyer, Ingrid Bergman, and Joseph Cotton. While hardly a victim of deception like Bergman's character, the sense of confusion and self-doubt was not entirely different.

7. While still "south of the border," I wrote John Willinsky for suggestions. With the exception of Saul, the list is his.

8. George Grant was born on November 13, 1918; he died on September 27, 1988. "A political philosopher who spent his most productive years teaching in a department of religion," Andrew Potter (2005) summarizes, "George Grant is probably best known today as the father of English-speaking Canadian nationalism" (p. ix). For Robin Lathangue (1998), a "public intellectual" (p. vii); for the distinguished American sociologist Seymour Martin Lipset (1990), Grant was "Canada's most distinguished conservative intellectual" (p. 36). The adjective "conservative" requires clarification, as the term connotes for Grant a different set of political preoccupations than it does in the US. "The truth of conservatism," Grant (1959/1966) wrote, "is the truth of order and limit, both in social and personal life. But obviously conservatism by itself will not do. For it can say nothing about the overcoming of evil, and at its worst implies that certain evils are a continuing necessity" (p. 108). Even at this stage - the late 1950s - Grant appreciated the concept's appropriation: "Yet to express conservatism in Canada means de facto to justify the continuing rule of the businessman and the right of the greedy to turn all activities into sources of personal gain" (p. 109).

9. See Grant (1965/2005).

10. Associated especially with John Dewey, whose work I still study today.

11. See Pinar (2009a).

12. "Place" is drenched in culture and politics and has a history. It is in contrast to the currently more fashionable term "space." See Pinar (2014), pp. 528-529, n. 12.

13. Grant may have well meant theological time with its promise of life after death, but I prefer Webster's fifth (secular) definition: "a seemingly endless or 
immeasurable time" (1975, p. 392), to emphasize the sense of duration non-coincidence with what is allows, however illusory or non-empirical it is in a scientific sense (see Pinar, 2011, p. 158, n. 11). Associated with the concept of "consciousness," this sense - "subject to no limitation or external determination" and "expanding indefinitely" (Webster's dictionary, 1975, p. 591: definitions \#1 and \#2 of “infinite") - allows us to experience the world, including ourselves, as "extending beyond, lying beyond, or being greater than any pre-assigned finite value however large" (Webster's dictionary, 1975, p. 591: definition \#3).

14. Contingency is my choice of concepts for the everyday, filled (or not so much) with events "of possible but uncertain occurrence" (Webster's dictionary, 1975, p. 246). While such events are often "dependent on or conditioned by something else," they are at the same time "not logically necessary... happening by chance or unforeseen causes" (definitions of "contingent" in Webster's dictionary, 1975, p. 246). Eternity and contingency, then, are interdependent concepts, interwoven realities. The everyday, the contingent, is then the "moving image of eternity," as our capacity to experience duration, to not coincide with what is, enables us to apprehend the everyday as images of the eternal.

15. Harold Innis was among the names - Charles Cochrane and Northrop Frye were others - Grant referenced in his report on philosophy in Canada for the Massey Commission. Innis and the others were thinkers "who have shown themselves willing to go beyond scholarship to more general questions of human import" (quoted in Christian, 1996a, p. 154). Grant judged Innis a scientist, not a philosopher: "He did not ask those questions which belong traditionally to philosophy... To put it mildly, the eternal was not his dish" (quoted in Christian, 1996a, p. 406, n. 13). Like George Grant, Innis had a "fundamentally conservative attitude towards modern democracy," evident in his critique of the United States (see Watson, 2007, p. 383). "Innis' intensely critical attitude towards the Liberal Party," Watson (2007) suggests, "was also similar to the later position of Grant" (p. 391). Grant later taught at McMaster, where Innis had studied for his undergraduate degree.

16. Grant was hardly the first to cite Hegel's famous phrase. Innis had chosen the myth of Minerva's owl to sketch his communications theory in an address to the Royal Society of Canada (as the newly elected President). For Innis, Watson (2007) explains, the owl represented those "living traditions" of the West that link us to the "oral tradition of the ancient Greeks" (p. 308). While the center of Western civilization moves from one people and place to another - symbolized by the owl's flight - cultural continuity can occur "only through the person-to-person dialogue of living individuals" (p. 308).

17. Summarizing Grant's report on philosophy for the Massey Commission, Christian (1996a) starts with Grant's key question: "How had it come to pass that we [philosophers in Canada] were so driven by immediacies and had lost sight of the eternal?" (p. 153). Grant's answers included Canadians' historic preoccupation with survival, allowing little time for "speculation ... [as] sureness and confidence were necessary for survival. Action was required and therefore contemplation was discouraged" (p. 153). More broadly, Grant located the press of the immediate in 
the "spiritual climate" in the West with its obsession with "knowledge for power," obscuring "those disciplines that once had been considered a potent influence in preventing us from becoming beasts" (quoted in Christian, 1996a, p. 153). Professors of philosophy - notably Fulton Anderson, head of Philosophy at the University of Toronto - took sharp exception (pp. 154-155) to Grant's critique of philosophy in Canada.

18. By philosophy, Grant (1959/1966) meant "a rigorous and consistent attempt to think the meaning of existence" (p. 5).

19. For details, see Pinar (2012, p. 104).

20. The US Supreme Court had intervened in its landmark 1954 desegregation ruling; Sputnik provided the provocation for more comprehensive Congressional action that incorporated then superceded the 1954 ruling (see Pinar, 2012, p. xvi).

21. In the curriculum reform that followed, the Kennedy Administration drew on arts and science faculty at Harvard University, demonstrating its confidence that academically rigorous research should be integral to national mobilization. The tale is much more twisted than that sentence communicates (as I explain in What Is Curriculum Theory?), but the Kennedy Administration's respect for academic elites does contrast with the attitude of the Canadian Prime Minister, as Grant (1965/2005) points out:

Diefenbaker's nationalism included contempt for the intellectual community, particularly the one found in the universities... Both Roosevelt and Kennedy found it useful to harness elements from the intellectual community to their administrations. Diefenbaker was unwise to treat the university community with the neglect and contempt that he did.

22. Holding the schools responsible for Sputnik was wrong empirically and morally, and imagining that academic expertise could transform a massive public institution like schools was mistaken as well, but Diefenbaker's error - Grant does not specify in what sense he regards it as "unwise" (politically, I suppose) - was of a different order altogether.

23. There had been building since the war criticism of the public schools as insufficiently focused on mathematics and science. Schools' post-war embrace of "life adjustment"(Pinar, 2012, p. 184) seemed too vague, even anti-intellectual, to those arts and science faculty now frustrated with teaching high-school graduates without adequate academic preparation, students who had not planned to attend university, until the GI Bill enabled them to do so. Before this criticism gained traction with the public, professional educators were clear in what they faced: "Wartime developments in technology are forcing revisions in the teaching of science and mathematics," Hilda Taba (1945, p. 80) appreciated. After Sputnik, public criticism became deafening:

"The sources of current criticism are multiple... Some, no doubt, represent a coalition of citizens opposed to school taxes, radicalism, and progressivism in education. A deepening concern over the expansion of Communism at home 
and abroad plays a role, as the instant reaction to the technical feat of Sputnik demonstrated" (Taba, 1962, p. 2).

But, she adds, "the strongest pressure for re-examination of the curriculum comes from the drastic changes in technology and culture, ranging from automation to atomic power, the voracious demands of the expanding industry on intelligent manpower" (p. 3).

24. Even Republican Party President Dwight D. Eisenhower warned Americans of the "military-industrial-complex." Less surprisingly, progressives like George Counts were worried as well (Gutek, 2006, p. 18).

25. Engineering here means remaking the world, including humanity, by design. "[W] hen the possibilities of technological tyranny had become obvious," Grant (1974/1998) observed, "the most popular academic theorizing about politics went no farther than the decent prescription that we ought to pursue 'piecemeal social engineering' so as to 'minimize misery"' (p. 51). Even that remnant of noblesse oblige has faded, and social engineering in US schools - in total contempt for the underclass - is conveyed now as confidence they can win the "race to the top."

26. See Pinar (2012), p. 163.

27. See, for instance, Seixas (2011), p. 141.

28. Not test preparation, but subjectively animated ethical engagement with alterity, enabled by academic knowledge: see Pinar (2006), p. 114; Pinar (2012), p. 231.

29. For a discussion of Marcuse's concept, see Savran (1998), pp. 34-35.

30. The phrase is Dwight D. Eisenhower's, who invoked it in his farewell to his fellow citizens: "In the councils of government, we must guard against the acquisition of unwarranted influence, whether sought or unsought, by the military-industrial complex. The potential for the disastrous rise of misplaced power exists and will persist." See http://coursesa.matrix.msu.edu/ hst306/documents/indust.html, accessed August 12, 2012.

31. I shared it: see Pinar (1974).

32. Grant (1969) decried the

"behaviorist psychology which now dominates our universities and which is geared to produce regulators who will fit the masses into the system by largely mechanical means. The humane if limited purposes of American Freudianism were not appropriate to the immensity of the institutions necessary to the overcoming of chance" (p. 131).

Later Grant (1974/1998) reiterated the point: "Whatever its defects, popular Freudianism is surely superior to the 'new brutalism' of behavior modification carried out by behaviorist techniques" (p. 104, n. 27). See Christian (1996a), p. 216. For a history of psychoanalysis in education, see Taubman (2011).

33. Of course, each of these is "subjective" in often irrecoverably indirect ways.

34. See Lasch, (1978, 1984). 
35. Technology erodes subjective coherence: see Pinar (2012), p. 225.

36. See note 16 , chapter I.

37. Not only do bookstores stay open past midnight in Buenos Aires, the city decided to give pensions to published writers in a program designed to strengthen the "vertebral column of society," as drafters of the law described their intention. Since its enactment in 2012, more than 80 writers have been awarded pensions, which can reach almost $\$ 900$ a month, supplementing other often meager retirement income. There are now plans to extend these pensions beyond Buenos Aires, though pensions are restricted to those 60 years of age or older who have written five books released by known publishing houses, ruling out self-published writers. Scholars and theoreticians need not apply, as the pensions are limited to writers of fiction, poetry, literary essays, and plays (Romero, 2012, August 13, p. A5).

38. See Taubman (2011). "For both neuroscientists and cognitive scientists," Taubman (2009) notes, "consciousness and subjectivity remain a puzzle... What they cannot explain is why we are obsessed with existential questions when we do not need them; why, that is, there is subjectivity" (p. 189). Given their inability to articulate "the experience and testimony of the individual mind," as Marilynne Robinson (2010) phrases it, many flee to "generalization, solemn efforts to tell our species what we are and what we are not, that were early salients of modern thought" (p. 22). Sociology and anthropology, she adds, are two "examples."

39. See Judt (2012).

40. See Pinar \& Irwin (2005).

41. See Macdonald (1995).

42. See Huebner (1999).

43. "The roots of anti-psychiatry lay within psychoanalysis," Zaretsky (2004, p. 327) explains. Anglo-American anti-psychiatry, exemplified by Ronald D. Laing, descended from British object-relations theory. Trained as a psychiatrist at the University of Glasgow, Laing joined the staff of the Tavistock Clinic in 1956, where he worked with D. W. Winnicott, Melanie Klein, and Susan Isaacs; he underwent an analysis with Charles Rycroft. For Laing, psychoanalysis was "the first lifting of the veil - the first detachment from the objects of consciousness to look at consciousness itself." In the early sixties, with Thomas Szasz and others, Laing began to depict schizophrenia as a category imposed on the individual by the psychiatrist, not as an intrapsychic condition. Michel Foucault was another advocate of anti-psychiatry: see Zaretsky (2004), p. 327. It was Laing and David Cooper who informed my first scholarship on the school: see Pinar (1975/2000).

44. Approximately $11 \%$ of US school-age children now receive a diagnosis of attention deficit hyperactivity disorder, some 6.4 million (Gup, 2013, April 3, p. A23). There are physicians to prescribe Adderall - not to treat ADHD necessarily, but to boost their academic performance (Schwarz, 2012, October 9, p. A1). Dr. William Graf, a pediatrician and child neurologist, expressed concern over the rising use of stimulants, threatening what he called "the authenticity of development." "These children are still in the developmental phase, and we still don't know how these drugs biologically affect the developing brain," he admitted (Schwarz, 2012, October 9, p. 
A18).

45. In the old Confederacy, these sometimes took the form of public signs demanding that children memorize the Ten Commandments, as if moral lapses occurred because people were simply uninformed (or, in Southern vernacular, "didn't know better").

46. It appears that here Grant mistakes "practicality" for the distinctively American philosophical tradition known as "pragmatism." While the former did emphasize the consequences of thought and action, it eschewed a vulgar utilitarianism. Despite Ravitch's revision of its history (see Ravitch, 2000), by the time of Dewey's death in 1952, pragmatism as an educational philosophy and movement had almost disappeared (see Cremin, 1961), replaced by a naked utilitarianism, first in the service of militarism, then economism. Grant's conflation of the two terms is definitionally but not historically mistaken. In his sometimes breathtaking analysis of pragmatism, Victor Kestenbaum (2002) reduces the distance between Grant and Dewey, if inadvertently. I hope to substantiate that claim in the book project from which this section is drawn.

47. See Tomkins (1986), p. 106; Christou (2012).

48. See McKnight (2002).

49. "In the broadest and most pressing terms," LaCapra (2004) points out, in effect updating Grant's nonetheless prescient analysis,

"a more or less relativized market model is active not only in the conception of a university itself as a corporation but in its status as the complement of private-sector business enterprises, a conception in which the university is based on knowledge as information, and information technology is dominant, from the primacy of the 'hard' sciences to the restructuring and 'digitalization' of the library, even to the point of continual technical 'upgrades' of systems that far exceed (or even counter) the needs of those who use libraries most, the humanists" (pp. 203-204).

Once the core disciplines of the university, the humanities are now, and not only in budgetary terms, ornamental.

50. Christian (1996a) tells us Grant found the "pedagogical writings of Dewey... useful precisely because they were shallow. Their very shallowness made it easy to see aspects of the modern, because they unwittingly exposed its presuppositions" (p. 194).

51. In mid-1941 - after the London raids had subsided and before his breakdown and return to Canada - Grant wrote to his mother that in a bookshop he had noticed John Dewey's Pedagogic Creed (originally published in 1897), which he considered "the complete justification, written well, of father's life... In philosophy my favorite philosophers are William James and John Dewey" (quoted in Christian, 1996a, p. 83; see also Christian, 1996b, p. 304). They don't remain his "favorites" for long, as after his conversion to Christianity ("likely on 11 or 12 December" [1941: see Christian (1996a), p. 85] - "he now saw that they [Dewey and James] started 
from the false premise that traditional education was somehow cut off from life. The truth was that both types of education aimed to produce a child who can look at life clearly" (Christian, 1996a, pp. 104-105).

52. "Law" is the rub, as for Dewey - if Kestenbaum (2002) is right - the sphere of the spiritual is by definition ineffable, certainly not codified.

53. For an intriguing and edifying intellectual history of historiography emphasizing issues of historical reconstruction, narrativization, and deconstruction, see Roberts (1995). "In shorthand terms," Roberts (1995) writes, in terms that Grant would not, I think, find mistaken,

"the element of infinity operates within finitude and results in finitude. There is no limit to the ways we, looking into the past, may sort things out, dividing and combining and relating, but not everything has happened, and thus even the totality is a particular. Still, the thickness of the particularity means that it is not to be confined to a single dominant strand - the dominant strand of the moment - but is always more even than the totality of our ways of understanding it" (p. 296).

54. See Grant (1986), p. 99.

55. See, for instance, Sztajn, Confrey, Wilson, \& Edgington (2012). While not yet mathematicized, this acronym-riddled graphed exposition maps a micromanaging of teaching and learning that ensures that neither could occur "openly" in Grant's sense.

56. See Pinar (Spring 2012, 2013).

57. "Indeed," Grant (1986) appreciates, "the word 'information' is itself perfectly attuned to the account of knowledge which is homogenizing in its very nature. 'Information' is about objects, and comes forth as part of that science which summons subjects to give us their reasons" (p. 24). Knowledge is a different matter, one requiring erudition, a subjective threading that enables judgment, on occasion, even wisdom. As Benjamin argued that art loses its aura in an age of mechanical reproduction (see, for instance, Petro, 2009, p. 261), information likewise lacks the subjective presence and professional judgment knowledge has imprinted within it.

58. His anti-abortion politics may outweigh his tendency toward anti-Semitism implied in his enthusiasm for Céline and Weil: see Bradshaw (1996).

59. I realize its historically specific form cannot be obscured in acknowledging its resurfacing in the "social justice" implied in "No Child Left Behind." Even President Obama's more athletic metaphor - "Race to the Top" - contains an implied promise that those left "behind" at the "starting gate" can (if "tested" enough, evidently in its mythological as well as trivial and tiresome sense) "win" in the end. What occurs in the end is a corporate closing of the American mind, barely open as it is.

60. One form the cosmopolitanism of Virginia Woolf took, Agathocleous (2011) explains, was the representation of "difference as experienced in time" (p. 191).

61. The phrase is John Toews' (2004). 


\section{References}

Agathocleous, T. (2011). Urban realism and the cosmopolitan imagination in the nineteenth century: Visible city, invisible world. Cambridge, England: Cambridge University Press.

Bradshaw, L. (1996). Love and will in the miracle of birth: An Arendtian critique of George Grant on abortion. In A. Davis (Ed.), George Grant and the subversion of modernity: Art, philosophy, politics, religion, and education (pp. 220-239). Toronto, Canada: University of Toronto Press.

Christian, W. (1996a). George Grant: A biography. Toronto, Canada: University of Toronto Press.

Christian, W. (1996b). Selected letters on universities and education by George Grant. In A. Davis (Ed.), George Grant and the subversion of modernity: Art, philosophy, politics, religion, and education (pp. 304-327). Toronto, Canada: University of Toronto Press.

Christian, W. (1995/2001). Editor's introduction: George Grant's Nietzsche. In G. Grant, Time as history (pp. vii-xli). Toronto, Canada: University of Toronto Press.

Christou, T. M. (2012). Progressive education: Revisioning and reframing Ontario's public schools, 1919-1942. Toronto, Canada: University of Toronto Press.

Dao, J. (2011, December 13). In California, Indian tribes with casino money cast off members. The New York Times, CLXI $(55,618)$, pp. A1, A22.

Fletcher, A. (2012). Allegory: The theory of a symbolic model. (With a foreword by Harold Bloom and a new afterword by the author). Princeton, NJ: Princeton University Press.

Foster, T. (2005). The souls of cyberfolk: Posthumanism as vernacular theory. Minneapolis, MN: University of Minnesota Press.

Gordon, R. S. C. (1996). Pasolini: Forms of subjectivity. Oxford, England: Clarendon Press.

Gouldner, A. W. (1970). The coming crisis of Western sociology. New York, NY: Basic Books

Grant, G. P. (1959/1966). Philosophy in the mass age. Toronto, Canada: Copp Clark Publishing.

Grant, G. (1969). Technology \& empire. Toronto, Canada: Anansi.

Grant, G. (1986). Technology and justice. Toronto, Canada: Anansi.

Grant, G. (1974/1998). English-speaking justice. Toronto, Canada: Anansi.

Grant, G. (1969/2001). Time as history. Toronto, Canada: University of Toronto Press.

Grant, G. (1965/2005). Lament for a nation. (40th anniversary ed.). Montreal and Kingston, Canada: McGill-Queen's University Press.

Greene, N. (1990). Pier Paolo Pasolini: Cinema as heresy. Princeton, NJ: Princeton University Press.

Gutek, G. L. (2006). George S. Counts and the origins of social reconstructionism. In K. L. Riley (Ed.), Social reconstruction: People, politics, perspectives (pp. 1-26). Greenwich, CT: Information Age Publishing.

Hadot, P. (1995). Philosophy as a way of life. (Edited and with an Introduction by Arnold I. Davidson). Oxford, England: Blackwell.

Huebner, D. E. (1999). The lure of the rranscendent. Mahwah, NJ: Lawrence Erlbaum.

Jay, M. (2005). Songs of experience: Modern American and European variations on a universal theme. Berkeley, CA: University of California Press.

Judt, T. (2012). Thinking the twentieth century. New York, NY: Penguin. 
Kestenbaum, V. (2002). The grace and severity of the ideal: John Dewey and transcendence. Chicago, IL: University of Chicago Press.

LaCapra, D. (2004). History in transit: Experience, identity, critical theory. Ithaca, NY: Cornell University Press.

Lathangue, R. (1998). Introduction to G. Grant, English-speaking justice (pp. vii-xxi). Toronto, Canada: Anansi.

Lipset, S. M. (1990). Continental divide: The values and institutions of the United States and Canada. New York, NY: Routledge.

Macdonald, J. B. (1995). Theory as a prayerful act. New York, NY: Peter Lang.

Nussbaum, M. C. (1997). Cultivating humanity: A classical defense of reform in liberal education. Cambridge, MA: Harvard University Press.

Petro, P. (2009). National Cinemas/International Film Culture: The Blue Angel (1930) in multiple language versions. In N. Isenberg (Ed.), Weimar Cinema (pp. 255-270). New York, NY: Columbia University Press.

Pinar, W. F. (Ed.). (1974). Heightened consciousness, cultural revolution and curriculum theory: The proceedings of the Rochester Conference. Berkeley, CA: McCutchan.

Pinar, W. F. (1975/2000). Sanity, madness and the school. In W. F. Pinar (Ed.), Curriculum theorizing: The reconceptualization (pp. 359-383). Troy, NY: Educator's International Press. (Originally published in Curriculum theorizing: The reconceptualists (pp. 359-383). Berkeley, CA: McCutchan.)

Pinar, W. F. (2006). The synoptic text today and other essays. Curriculum development after the reconceptualization. New York, NY: Peter Lang.

Pinar, W. F. (2009a). The worldliness of a cosmopolitan education: Passionate lives in public service. New York, NY: Routledge.

Pinar, W. F. (2009b). The primacy of the particular. In L. Waks and E. C. Short (Eds.), Leaders in curriculum studies: Intellectual self-portraits (pp. 143-152). Rotterdam, Netherlands, and Taipei, Taiwan: Sense Publishers.

Pinar, W. F. (2011). The character of curriculum studies: Bildung, currere, and the recurring question of the subject. New York, NY: Palgrave Macmillan.

Pinar, W. F. (2012). What is curriculum theory? (2nd ed.). New York, NY: Routledge.

Pinar, W. F. (2013). Curriculum studies in the United States. Intellectual histories, present circumstances. New York, NY: Palgrave Macmillan.

Pinar, W. F. (2014). Curriculum research in the United States: Crisis, reconceptualization, internationalization. In W. F. Pinar (Ed.), International handbook of curriculum research (pp. 521-532). (2nd ed.). New York, NY: Routledge.

Pinar, W. F., \& Irwin, R. L. (Eds.). (2005). Curriculum in a new key: The collected works of Ted T. Aoki. Mahwah, NJ: Lawrence Erlbaum.

Potter, A. (2005). Introduction to the 40th anniversary edition of G. P. Grant, Lament for a nation (pp. ix-lxviii). Montreal and Kingston, Canada: McGill-Queen's University Press.

Radhakrishnan, R. (2008). History, the human, and the world between. Durham, NC: Duke University Press.

Ravitch, D. (2000). Left back: A century of battles over school reform. New York, NY: Simon and Schuster.

Roberts, D. D. (1995). Nothing but history: Reconstruction and extremity after metaphysics. 
Berkeley and Los Angeles, CA: University of California Press.

Robinson, M. (2010). Absence of mind: The dispelling of inwardness from the modern myth of the self. New Haven, CT: Yale University Press.

Romero, S. (2012, August 13). Argentina's new literary tradition - Pensions for aging writers. The New York Times, CLXI (55, 862), p. A5.

Santner, E. L. (2006). On creaturely life: Rilke, Benjamin, Sebald. Chicago, IL: University of Chicago Press.

Schwarz, A. (2012, October 9). Attention disorder or not, pills to help in classroom. The New York Times, CLXII(55, 919), pp. A1, A18.

Seixas, P. (2011). Assessment of historical thinking. In P. Clark (Ed.), New possibilities for the past: Shaping history education in Canada (pp. 139-153). Vancouver, Canada: University of British Columbia Press.

Spring, J. (2012). Education networks: Power, wealth, cyberspace, and the digital mind. New York, NY: Routledge.

Sztajn, P., Confrey, J., Wilson, P. H., and Edgington, C. (2012, June-July). Learning trajectory based instruction: Toward a theory of teaching. Educational Researcher, 41(5), 147-156.

Taba, H. (1945). General techniques of curriculum planning. In the National Society for the Study of Education, American education in the post war period: Curriculum reconstruction. Forty-fourth Yearbook, Pt. 1 (ch. 5, pp. 80-115).

Taba, H. (1962). Curriculum development: Theory and practice. New York, NY: Harcourt, Brace \& World.

Taubman, P. M. (2009). Teaching by numbers: Deconstructing the discourse of standards and accountability in education. New York, NY: Routledge.

Taubman, P. M. (2011). Disavowed knowledge. New York, NY: Routledge.

Toews, J. (2004). Becoming historical: Cultural reformation and public memory in early nineteenth-century Berlin. New York, NY: Cambridge University Press.

Tomkins, G. S. (1986). A common countenance: Stability and change in the Canadian curriculum. Scarborough, Ontario: Prentice-Hall. (Reprinted in 2008 by Pacific Educational Press).

Watson, A. J. (2007). Marginal man: The dark vision of Harold Innis. Toronto, Canada: University of Toronto Press.

Webster's new collegiate dictionary. (1975). Springfield, MA: G. \& C. Merriam Company.

Williams, T. (2012, August 9). \$1 million each year for all, until tribe's luck runs out. The New York Times, CLXI (55, 858), pp. A1, A4.

Zaretsky, E. (2004). Secrets of the soul: A social and cultural history of psychoanalysis. New York, NY: Alfred A. Knopf. 